\title{
Enterobius vermicularis: A rare Cause of Appendicitis
}

\section{Enterobius vermicularis: Apandisitin Nadir Bir Nedeni}

\author{
Eleftherios Gialamas ${ }^{1}$, Theodossis Papavramidis ${ }^{1}$, Nick Michalopoulos ${ }^{1}$, \\ Georgia Karayannopoulou², Angeliki Cheva², Olga Vasilaki³, Isaak Kesisoglou1, \\ Spiros Papavramidis ${ }^{1}$
}

'Department of $3^{\text {rd }}$ Surgery, Aristotle University of Thessaloniki, Thessaloniki, Greece

'Department of Pathology, Aristotle University of Thessaloniki, Thessaloniki, Greece

${ }^{3}$ Department of Microbiology, Aristotle University of Thessaloniki, Thessaloniki, Greece

\section{ABSTRACT}

Objective: Although appendicitis is one of the most common causes of emergency surgery, parasites are rarely found associated with inflammation of the appendix. The aim of this study is to establish the prevalence of Enterobius vermicularis in surgically removed appendices, as well as to determine its possible role in the pathogenesis of appendicitis.

Methods: A retrospective analysis of all the appendices removed during the last 20 years at a tertiary university hospital. Appendices removed during the course of another intra-abdominal procedure were excluded from the study.

Results: All 1085 surgical specimens removed from patients with clinical appendicitis were evaluated. Enterobius vermicularis was found in seven appendices $(0.65 \%)$ with clinical symptoms of appendicitis. The parasite was most frequently identified in appendices without pathological changes (6/117). There was no case of chronic appendicitis presenting E. vermicularis infestation, while the parasite was rarely related to histological changes of acute appendicitis (1/901).

Conclusion: The results suggest that the presence of E. vermicularis in the appendix might cause appendiceal pain (colic), but can rarely be associated with pathologic findings of acute appendicitis. (Turkiye Parazitol Derg 2012; 36: 37-40)

Key Words: Appendicitis, Enterobius vermicularis, appendiceal oxyuriasis, worm appendicitis

Received: 17.04.2011

Accepted: 03.02.2012

\section{ÖZET}

Amaç: Apandisit, acil cerrahinin önde gelen nedenlerinden biri olmakla birlikte parazitler, apendiks inflamasyonu ile nadir olarak ilişkili bulunmaktadır. Bu çalışmanın amacı, Enterobius vermicularis'in, cerrahi olarak çıkarılmış apendikslerde prevalansını saptamak ve apandisit patogenezinde olası rolünü belirlemektir.

Yöntemler: Üçüncü basamak bir üniversite hastanesinde, son 20 yıl içinde opere edilmiş tüm apendikslerin retrospektif incelemesi yapıldı. Farklı bir sebeple yapılan intraabdominal cerrahi esnasında çıkarılmış olan apendiksler çalışmaya dahil edilmedi.

Bulgular: Apandisit klinik şüphesi ile opere edilen olgulardan elde olunan 1085 cerrahi materyal değerlendirildi. Apandisit klinik bulgusu olan olguların yedi tanesinde (\%0.65) apendikste Enterobius vermicularis saptandı. Parazite en sık olarak patolojik değişiklik görülmeyen apendikslerde rastlandı (6/117). E.vermicularis enfestasyonu olan hiç bir kronik apandisit olgusu tespit edilmedi ve parazit, nadir olarak akut apandisitin histolojik değişiklikleri ile ilişkili bulundu (1/901).

Sonuç: Çalışmanın sonuçları, apendikste E. vermicularis varlığının, apendiks ile ilişkili ağrıya (kolik) neden olabileceğini ancak akut apandisitin patolojik bulguları ile nadiren ilişkili olduğunu göstermektedir. (Turkiye Parazitol Derg 2012; 36: 37-40)

Anahtar Sözcükler: Apandisit, Enterobius vermicularis, oksiyüriazis, kıl kurdu apandisiti

Geliş Tarihi: 17.04.2011

Kabul Tarihi: 03.02.2012

Address for Correspondence / Yazışma Adresi: Dr. Theodossis Papavramidis, Department of $3^{\text {rd }}$ Surgery, Aristotle University of Thessaloniki, Thessaloniki, Greece Phone: 00306944536972 Fax: 00302310420293 E-mail: papavramidis@hotmail.com doi:10.5152/tpd.2012.09 


\section{INTRODUCTION}

Acute appendicitis (AA) is considered as the most common cause of emergency surgery $(1,2)$. The aetiology of AA rarely involves parasitic and protozoal infections of the gastrointestinal tract in the developed countries (3). Inversely, many parasitic infections frequently lead to the symptomatology of acute appendicitis.

It is exactly this ambiguous relation between parasitic infections and $A A$ that still induces a controversy as to whether or not these parasites may cause appendicitis, despite the fact that many parasites have been found in the lumen of the appendix (4).

Human infestation with Enterobius vermicularis (pinworm, seatworm, threadworm, oxyuriasis) has been recognized for about 10,000 years, and the presence of the parasite in the appendix was first recognized by Fabrius in 1634 (5). The mature worm of E. vermicularis lives and reproduces in the proximal part of the ascending colon, caecum, appendix and the terminal ileum. After fertilization, the male worm dies while the female migrates to the anal canal where the laying of eggs takes place (6).

The aim of this study was to establish the prevalence of E. vermicularis in appendectomy specimens and to determine its possible role in the pathogenesis of appendicitis.

\section{MATERIAL AND METHODS}

This is a retrospective analysis of all the appendices that were removed between 1 January 1987 and 31 December 2008 by the surgeons of the $3^{\text {rd }}$ department of surgery of AHEPA University Hospital of Thessaloniki. All 1085 surgical specimens removed at operation from patients with clinical appendicitis were evaluated. Appendices removed during the course of another intraabdominal procedure were excluded from the study.

The appendices were fixed in 10\% formalin. All blocks were stained with haematoxylin and eosin and examined for the presence of $E$. vermicularis and the type of inflammation.

\section{RESULTS}

A total of 1085 patients with appendicitis were examined. 584 among them were males (53.83\%), while 501 were females (47.17\%). The mean age of the patients was 27.62 years (SD 14.45 years), ranging from 8 to 96 years.
Histological examination revealed features of acute appendicitis in $83.04 \%$ (901), chronic appendicitis in 6.18\% (67) and no inflammation in $10.78 \%$ (117) of appendices (Table 1). E. vermicularis was found in seven appendices, all of which were from patients with clinical symptoms of appendicitis. The prevalence of $E$. vermicularis was $0.65 \%$ in cases of clinical appendicitis. The ages of the patients with histologically proven E. vermicularis in appendices ranged from 15 to 33 years with a median age of 25 years. Of seven cases, four were women and three were men. In patients with clinical appendicitis, E. vermicularis was most frequently identified in appendices without pathological changes $(6 / 117,5.13 \%)$ while only one of the 901 cases of acute appendicitis $(0.11 \%)$ showed evidence of infestation (Table 1$)$. All seven cases showed characteristic features of $E$. vermicularis adult worms in the lumen of the appendix. In the case where acute appendicitis was present, the worm was found in the lumen of the appendix without any relation to the epithelium and with prominent signs of inflammation (Figure 1).

\section{DISCUSSION}

The various worms that have been reported to be associated with clinical appendicitis include: Ascaris lumbricoides (round worm), Trichuris trichuria (whip worm), Entamoeba histolytica and Enterobius vermicularis (6). Intraluminal parasites within resected appendix specimens are generally an incidental finding. Gastrointestinal infection due to Enterobius vermicularis occurs worldwide and is considered to be the most common helminthic infection. Although seen in all ages and socioeconomic levels, there is a distinct predilection for children and the young (7). Whilst most children are asymptomatic, the most common presenting symptom is pruritis ani, but infestation may present with ileocolitis, enterocutaneous fistula, urinary tract infection, mesenteric abscesses, salpingitis and appendicitis (8).

As previously mentioned, the mature worm of E. vermicularis lives in the proximal part of the ascending colon, caecum, appendix and the terminal ileum, and represents the most common parasite found in the appendix. The recent literature revealed the incidence of $E$. vermicularis in surgically removed appendices from patients with clinical appendicitis, varying from $2.7 \%$ to $4.1 \%$ (6). In our study, E. vermicularis was identified only in $0.65 \%$ of patients with clinical appendicitis and overall $0.60 \%$ for all appendices removed during the same period. This lower

Table 1. Demographic parameters and histological findings of patients

\begin{tabular}{|c|c|c|}
\hline & $\begin{array}{c}\text { Patients with clinical appendicitis } \\
(\mathbf{n = 1 0 8 5 )}\end{array}$ & $\begin{array}{c}\text { Patients with clinical appendicitis and } \\
\text { E. vermicularis infection } \\
\text { (n=7) }\end{array}$ \\
\hline Age (years) & 27.62 (SD 14.45) \\
\hline Sex & & 25 \\
\hline Male & 584 & 3 \\
\hline Female & 501 & 4 \\
\hline Histological findings & & 1 \\
\hline Acute inflammation & 901 & - \\
\hline Chronic inflammation & 67 & 6 \\
\hline No inflammation & 117 & \\
\hline
\end{tabular}




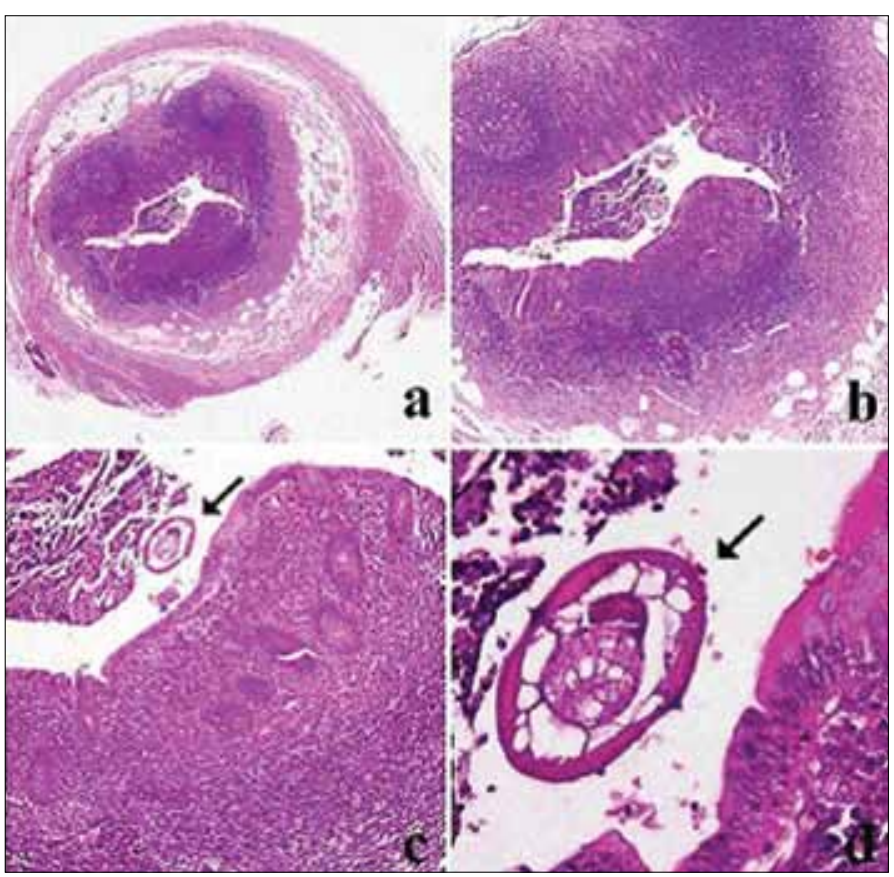

Figure 1. The histological spectrum of appendicitis associated with E. vermicularis infection. a) Acute appendicitis: there is hemorrhagic ulceration of the mucosa. All coats of the wall of the appendix are markedly thickened by oedema and an infiltrate of inflammatory cells. $\mathrm{H} \& \mathrm{E}, \times 25$. b) Acute appendicitis. $\mathrm{H} \& \mathrm{E}, \times 40$. c) Enterobius vermicularis in the lumen of the appendix (arrow). $H \& E, \times 100$. d) Cross-section of the worm (arrow). H\&E, $\times 400$

prevalence could be justified by two factors. The first one is the geographic location and social circumstances, leading to prominent variations in the prevalence of the parasite. The other factor could possibly be the existence of minimal differentiations in the techniques followed by the pathologists. There is also evidence to suggest that a histologically normal appendix may show molecular evidence of inflammation if examined further (8). Concerning the sex incidence of $E$. vermicularis and its relation to inflammation, the results of the study of Williams and Dixon indicate that there is no relationship between the sex of appendiceal Enterobius and inflammation. It is also surprising to note that male pinworms are more commonly seen than females in view of the greater size of the latter (9).

Despite the fact that the relationship of E. vermicularis to the pathogenesis of appendicitis has been investigated for many years, the influence of the parasite on the individual forms of inflammation is still unclear (6). Although E. vermicularis may have a causal role in appendiceal pain and chronic inflammation due to obstructive phenomena, the overwhelming majority of cases are not associated with acute inflammation. Interestingly, the presence of pinworms in the appendix may cause a clinical "appendiceal syndrome" even without eliciting acute inflammation (7). This "syndrome", also mentioned as appendiceal colic, consists of chronic right lower quadrant and pelvic pain, intermittent in nature, and can be explained by the hypothesis of appendiceal lumen obstruction. The situation in acute appendicitis is less clear. In the few cases where E. vermicularis is found in association with acute inflammation, it may be that the worm has been responsible for initiating the inflammatory reaction, although this and other studies suggest that its presence may be coincidental (10). In keeping with previously published reports, in our study there is only one of the 901 cases of acute appendicitis $(0.11 \%)$ showing evidence of $E$. vermicularis infestation. It is important, however, to mention that all of our seven patients, diagnosed eventually with E. vermicularis infection, presented symptoms of clinical appendicitis, whether the latter was typical or not.

With regards to histopathology, E. vermicularis is rarely associated with the histological changes of acute appendicitis. Similarly, Wiebe et al. (11) recently revealed a highly significant difference in the incidence of $E$. vermicularis in normal appendices and in inflamed appendices. The present study strongly supports the previous bibliographic data. In other cases, E. vermicularis infestation of the appendix may cause a spectrum of pathologic changes in the appendix that range from lymphoid hyperplasia to life-threatening complications such as gangrenous appendicitis and perforation with peritonitis. Lymphoid hyperplasia in response to the presence of the parasite may be the first tissue reaction leading to clinical signs of appendiceal colic. On the other hand, the obstructive effect because of the prominent lymphoid tissue may be the initiating event for the inflammatory process (3). Sterba and Vlcek found that the number of granulomas in appendices infested with E. vermicularis far exceeded the number of granulomas in a control group of noninfested appendices. Morgensen et al. have shown that, apart from simply causing granuloma formation, E. vermicularis can also invade the wall of the appendix leading to inflammation (10). A literature search showed a single case of mucosal invasion and intramural location of E. vermicularis in a patient with symptoms of acute appendicitis. Sah and Bhadani described in their study two cases of acute appendicitis, in which eggs of the parasite were attached to mucosa in one case and in another $E$. vermicularis had invaded the mucosa and was lying intramurally. However, presumably the worms had just been caught by the severe inflammation in these two cases of acute appendicitis (6).

It is acceptable that the correct diagnosis can be achieved after co-assessment of the patient's history, physical examination and laboratory findings, as well as radiological imaging. In many cases, the doctor has to overcome the difficulties arising from the ambiguity of the clinical symptoms and the significant variations of laboratory results. Laboratory exams may show leucocytosis, but in most cases the WBCs are normal, and diagnosis may be made by the eosinophilia and the positive stool examination. In equivocal cases, the diagnostic certainty can be improved by the addition of radiological imaging. In cases of suspected appendicitis, ultrasound and computed tomography (CT) have proven to be beneficial, with reported sensitivities of $95 \%$ and $96 \%$, respectively, and with negative predictive values of $99 \%$, and the negative appendectomy rate in current practice continues to decline (8). Some patients for whom appendectomy is not clinically indicated may also benefit from night-time application of cellophane tape in the perianal area (8). Concerning the differential diagnosis, it is true that an appendiceal colic caused by pinworm infestation cannot be differentiated from the right lower quadrant pain of usual acute appendicitis. In some cases a 
careful history may point to antecedent symptoms and a time course incompatible with typical appendicitis, but physical examination is generally not specific enough to differentiate between parasitic and ordinary appendiceal pain (7).

Patients should be clinically observed and re-evaluated before being subjected to an emergency appendectomy. However, the abdominal discomforts that they present and missing the diagnosis leads to inevitable surgical operation. Appendectomy, open or laparoscopic, should proceed with caution if the appendix is observed not to be acutely inflamed. The surgeon must bear in mind the possibility of resident worms in the vermiform appendix (7). The diagnosis of pinworm infestation can be generally reached only after the histopathologic observation of the resected appendices. In order to achieve the best therapeutic result, all patients should routinely receive antihelminthic treatment afterwards, because the appendectomy treats only the symptoms and not the primary cause of the disease. The treatment of $E$. vermicularis infection involves one dose of pyrantel pamoate $11 \mathrm{mg} / \mathrm{kg}$, or mebendazole $100 \mathrm{mg}$ orally with a second dose in 2 weeks to treat possible re-infection. It is also recommended that family members are treated in order to eliminate asymptomatic reservoirs and to ensure eradication (12).

Enterobius vermicularis is the most common parasite found in the appendix. Although its presence may play a causal role in appendiceal pain and chronic inflammation, it is rarely related to acute appendicitis. E. vermicularis infestation of the appendix usually produces an "appendiceal syndrome", characterized by chronic intermittent pain in the right iliac fossa. The appendix may be histologically normal, but in many cases it shows various pathologic changes. Commonly, patients are subjected to an emergency appendectomy, but the final diagnosis can only be reached after pathologic examination of the appendix. All patients diagnosed with $E$. vermicularis infestation of the appen- dix should receive antihelminthic treatment in order to prevent possible re-infection.

\section{Acknowledgement}

The authors would like to thank Dr. Begum Demirler for the cooperation and the translation of the necessary parts in Turkish.

\section{Conflict of Interest}

No conflict of interest was declared by the authors.

\section{REFERENCES}

1. Jones PF. Suspected acute appendicitis: trends in management over 30 years. Br J Surg 2001; 88: 1570-7. [CrossRef]

2. Zielke A. Appendicitis: present-day diagnosis. Chirurg 2002;73:78290. [CrossRef]

3. da Silva DF, da Silva RJ, da Silva MG, Sartorelli AC, Rodrigues MA. Parasitic infection of the appendix as a cause of acute appendicitis. Parasitol Res 2007; 102: 99-102. [CrossRef]

4. Dorfman S, Talbot IC, Torres R, Cardozo J, Sanchez M. Parasitic infestation in acute appendicitis. Ann Trop Med Parasitol 1995; 89: 99-101.

5. Fry FG, Morre JG. Enterobius vermicularis, 10,000-year-old human infection. Science 1969; 166: 1620. [CrossRef]

6. Sah SP, Bhadani PP. Enterobius vermicularis causing symptoms of appendicitis in Nepal. Trop Doctor 2006; 36: 160-2. [CrossRef]

7. Aydin O. Incidental parasitic infestations in surgically removed appendices: a retrospective analysis. Diagnost Pathol 2007; 2: 16. [CrossRef]

8. Sodergren MH, Jethwa P, Wilkinson S, Kerwat R. Presenting features of Enterobius vermicularis in the vermiform appendix. Scand $J$ Gastroenterol 2009; 44: 457-61. [CrossRef]

9. Williams DJ, Dixon MF. Sex, Enterobius vermicularis and the appendix. Br J Surg 1988; 75: 1225-6. [CrossRef]

10. Budd JS, Armstrong C. Role of Enterobius vermicularis in the aetiology of appendicitis. Br J Surg 1987; 74: 748-9. [CrossRef]

11. Wiebe BM. Appendicitis and Enterobius vermicularis. Scand J Gastroenterol 1991; 26: 336-8. [CrossRef]

12. Nackley AC, Nackley JJ 2nd, Yeko TR, Gunasekaran S. Appendiceal enterobius vermicularis infestation associated with right-sided chronic pelvic pain. JSLS 2004; 8: 171-3. 